\title{
Formation of Student Management Activities in the Higher Education Management System
}

\author{
AbralovaZabarjat Djuraevna ${ }^{1}$ \\ ${ }^{1}$ Researcher of Tashkent State Pedagogical University
}

\begin{abstract}
The article describes the concept of educational management, the scientific work of scientists studying management problems, the principles of modern management, the organization of experimental work in the research process and the implementation of the results in practice.
\end{abstract}

Keywords: management, manager, principles of management, organization of management on a scientific basis, theory "Path-goal"

Article Received: 16th October, 2020; Article Revised: 30th December, 2020; Article Accepted: 08th January, 2021

The reformed system of continuing education includes a system of education authorities at all levels, as well as subordinate institutions, organizations and enterprises. "Therefore, we consider the improvement of joint management of the educational institution and the educational process as one of the most promising areas for the introduction of scientific work and practical measures to improve the quality of education," wrote Sh.E. Kurbanov and E.A. Seytkhalilov. Their monograph is a significant contribution to the science of management of the education system.

With the study of management problems in Uzbekistan R.H.Djuraev, Sh.E.Kurbanov, E.Imamov, L.Peregudov, O.Salimov, M.Saidov, E.Seytkhalilov, H.Rashidov, A.Khodjibaev, R.Sh. Axletdinov, U.I.Inoyatov, U. Mahkamov, M.Sharifkhodjaev, S.Turgunov, J.G.Yuldashev, A.A.Yuldashev, Ya.Ismadiyarov and others.

M.M. Potashnik, R. Folmerh, Yu.I. Dick, L.S. Jacobson, G. Kunts, G. Benveniste, U. Braddick, A. Bouve, U were involved in the development of various areas of education management in Russia and abroad. .Iox, G.M.Kirilenko, V.S.Lazarev, M.Jonson,
V.P.Bespalko, B.Skatkin, P.Byuler, K.Ya.Vazina, M.Vudkok, D.Frensis, L.I

Lukicheva, M.H.Meskon, M.Albert, F.Hedouri, F.Rodgers, M.Stettner, A.Fayol, G.Emerson, F.Taylor, G.Ford, L.Yakkoka and others devoted their scientific works. These works reveal some issues of management of educational institutions: the role and place of education management in meeting the needs of the state, society and the individual; conceptual ideas about the social nature of pedagogical management; scientific and theoretical issues of school principal management; TM organization and management methods; personnel issues of management; modern management; comparative management (compares the development of management in Japan, USA, UK, Germany, Switzerland, China and other countries) and b. "I see management as a unique way of looking at management that transforms an unorganized crowd into an effective, goal-oriented, and productive group," says Peter Drucker. When it comes to firms and businesses, this definition needs to be clarified.

Management is the process of directing an enterprise to its intended purpose using resources in the best 
possible way. However, we are interested in managing an educational institution. The following definition can be considered the most complete.

Management is a type of management of activities aimed at achieving the goals of an educational institution, taking into account the satisfaction of people with their work, using their labor, intellect and moral motives.

Management is the professional implementation of any economic activity of the organization in market conditions, aimed at earning income through the rational use of resources.

Management is a unique dynamic organization of management, which is necessary for an economically independent entity, a flexible system of entrepreneurship and innovation leadership that is able to respond to market conditions, competitive conditions and timely self-reconstruction taking into account the requirements of the external environment. Management as a type of education management has the following distinctive features:

* human orientation;

* student orientation;

* full orientation to the educational institution;

* Continuous improvement of the management system of the educational institution.

Principles of management are the basic ideas, laws and rules of the activity of the leader to perform management functions. Principles of modern management:

- The principle of optimal combination of centralization and decentralization in management, the optimal distribution of powers in management decision-making; - The principle of skillful use of individualism and collegiality in management;

- The principle of scientific substantiation of management;
- the principle of planning;

- the principle of combining rights, obligations and responsibilities;

- The principle of motivation;

- The principle of democratization of governance.

Management is inextricably linked with the people (managers) who are engaged in management.

A manager is a person who holds a permanent management position and has the authority to make decisions on certain types of activities of the organization operating in market conditions. Managerial labor is more intellectual and creative. Modern management integrates them into the management process, taking into account the achievements of all schools and areas. The main conditions of the system of modern approaches to management (related to the pedagogical discipline "new management paradigm") are:

- abandonment of management rationalism of classical management schools;

- use of systems theory in management;

- application of situational approach to management;

- Recognition of the social responsibility of management before both society and individual employees of the organization.

Management is inextricably linked with the people (managers) who are engaged in management. There are people who think that if you want to do something right, you should do it yourself. People with such an understanding can rarely be a good leader or manager because they find it difficult to delegate responsibility to others. They delegate to others only trivial tasks, leaving important tasks to themselves. As a result, they also work in the evenings and on weekends, as well as take some work home. 
There is nothing wrong with overworking. Most people have to spend extra time at work from time to time, but those who have become a way of life are bad managers. They don't trust their subordinates, they don't trust anyone to do important things. In fact, employees tend to get very tired of dealing with things that are usually more skilled. Managers who "do everything" believe that their subordinates do not take responsibility. Leaders never admit that they don't want to delegate responsibility to others.

Another distinguishing feature of "all-inclusive" managers is that they rarely take a full vacation. They only go for two to three days because the institution believes they can't keep you going for long. Before they leave, they make special instructions about what to do until they return. In some cases, they leave a phone number that can be contacted in an unexpected situation. And of course, they clearly show what unexpected situations can consist of.

The challenges facing managers in the 21 st century require new skills. Acting according to the old rules cannot lead to success in today's rapidly changing world. The manager must be a well-rounded person and have a very comprehensive set of skills. To be an effective manager, it is necessary to master the new rules of operation. Today, the situation in education is changing rapidly with immeasurable inequality. Accordingly, R. House distinguishes three methods of leadership behavior:

- directive (guiding) leader. Explains in detail to subordinates what the organization expects of them; plans in detail the course of the whole work process and gives clear instructions about it. Explains in detail how to perform this or that task;

- supportive leader. Distinguished by his friendliness and concern for the needs of his subordinates;

- Participatory leader. Consults with subordinates and takes their opinions into account in the decision-making process. Unlike F. Fidler, R. House substantiates his theory that leaders are characterized by flexibility. According to the path-goal theory, only one leader can use the different methods described above, depending on the situation.

As can be seen from Figure 1, the path-goal theory somewhat softens the relationship between the two classes of situational factors: the leader's behavioroutcome: variable, dependent on the external environment, beyond the control of subordinates (as well as task structuring, the nature of the formal system of powers; factors such as community characteristics); the variable is often part of the personal description of the follower (subordinate) (level of self-control, experience and skills of the employee).

External environmental factors determine the types of behavior that will be necessary for a manager in cases where it is necessary to ensure maximum employment of subordinates; the personal characteristics of subordinates determine how they perceive and interpret the situation in the environment as well as the leader's actions.

According to the "goal-orientation" theory, a leader's behavior is ineffective if it is over-directed to external environmental factors, or if it does not take into account the characteristics of his subordinates. We express a number of hypotheses based on the theory of "pathgoal". 


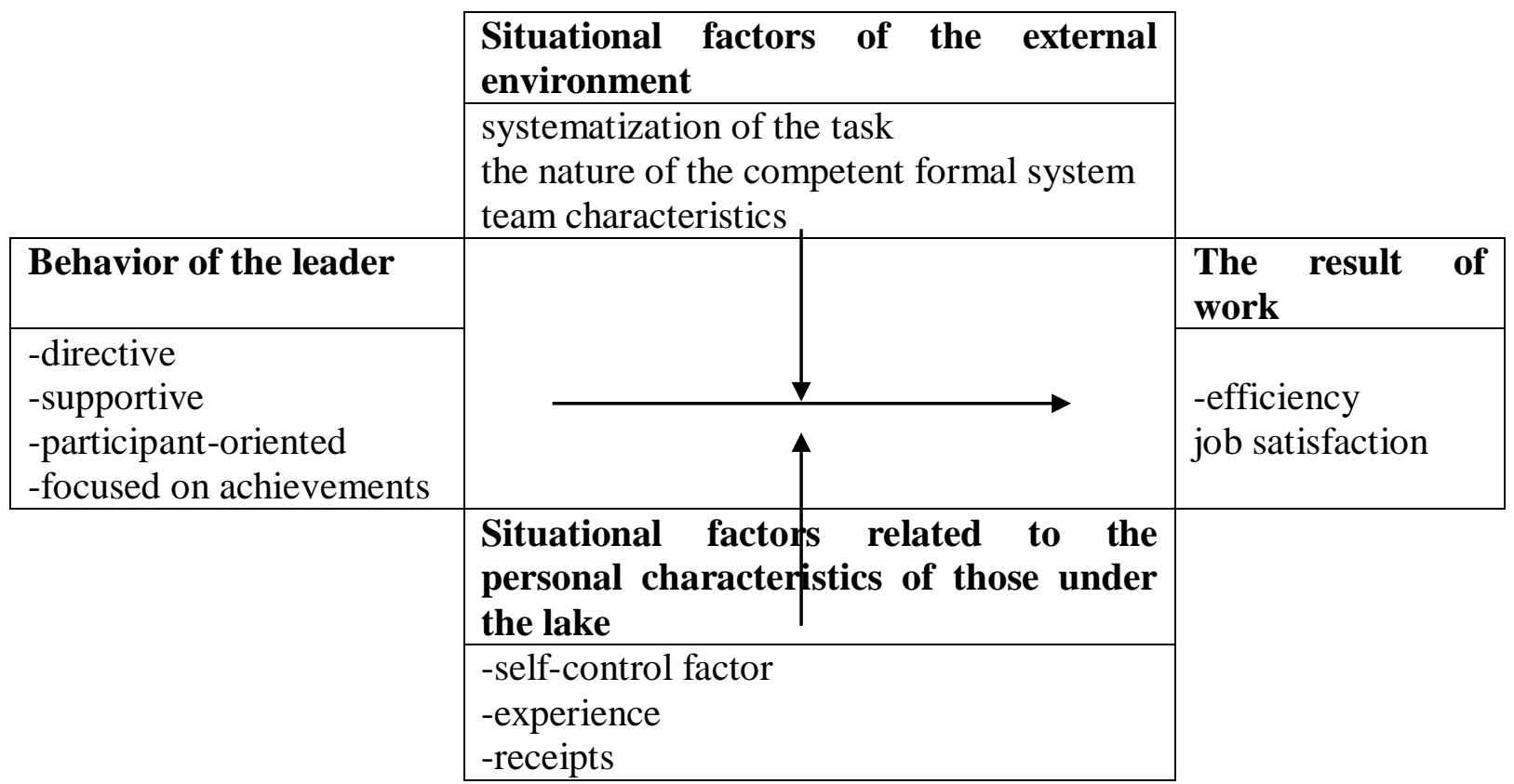

Figure 1. Theory of purpose.

The work of a manager is not only objective, but also creative, enterprising, so it would be very appropriate to talk about the managerial art of management. It is this that determines his approach to the problem of organizing his labor. On the one hand, the organization of the manager's work is subject to certain laws, principles, rules, on the other hand - these rules are very conditional and require creative thinking to determine the degree of their application to the work of a given manager in a given situation. The rules here only serve as a starting point for the manager to actively work on improving his work style, skills and abilities, methods of organizing his work.

The manager must take the initiative within certain legal norms, develop team initiative and therefore feel fully responsible for their actions and their results. This increases the role of the manager in the management system.

The autocrat is against the diplomat. It's hard to believe that there is an old-fashioned autocrat in today's administration. I wonder why? Most managers, because they are unprepared, look for their own path independently and behave as they see fit. They consider themselves the boss. Autocrats are also afraid that servants will take advantage of this and see such an attitude as a weakness.

The autocrat loves to make all the decisions himself and believes that his subordinates should follow his orders just like robots. The autocrat presses the buttons, the staff gets to work, and the job is ready. The diplomat knows that the time spent trying to get everyone to work will pay off and bring in a huge investment.

The diplomat sees the autocrat as a dictator. The difference is that the autocrat always uses authority, while the diplomat leads based on the demonstration of common sense.

People who work under an autocrat think they are working for someone. Those who report to a diplomat believe they will work with someone.

Managers who are just starting out should take an "alert approach" and choose the appropriate leadership style. To be an alert, the manager must calculate the control and incentives for each employee. While the manager is in control, he shows the employees what to do, how to do it, and how to get the job done on time. The manager motivates, motivates, listens attentively, and sometimes tells employees that they need to do the required work. 
Some employees need constant supervision and constant encouragement. And for others - almost not necessary. There are those between them. To take advantage of the alert approach, the manager must determine what each employee needs from him or her while choosing a leadership style. The manager needs to understand how much control and motivation is needed.

The level of control and motivation required for each employee will depend on what the manager is working on and what is happening in the department.

Creating a healthy, creative environment in the team is an important task of a manager. He must rely on the team in all his actions, reckoning with his opinion. In creating a good psychological environment in the team, the reputation that the manager earns in the service position, mainly achieved through his business and moral qualities, plays a big role.

Team leadership is inextricably linked with nurturing the individual. Understanding the whole complexity and subtleties of the mechanism of psychological connections between the team and the individual is an important requirement for a modern method of managerial work.

21 st century managers face very complex challenges of leadership and leadership.

Today, the effectiveness of management and leadership depends more than ever on whether a leader gains the trust of his subordinates (teachers, students) and does not lose it. For example, frequent staff reductions, incidents such as quarrels in the organization undermine employees 'trust in their leader.

Our research has shown that especially learning-type organizations need an effective leader. First, it was found that some people do not have the qualities needed to be a leader. Experience has shown that a leader can be trained in confidence building and mentoring skills. A leader can acquire the skills of situation analysis, that is, how to evaluate situations, how to modify them to suit his or her leadership style, and how to fanatically choose a behavioral style that is more appropriate to the situation.

The organization of experimental work and the implementation of the results in practice meant that the experiment will be conducted in three stages.:

1. Researcher (2010). At this stage, the scientific literature on the research topic was studied and ways to develop a concept of development of managerial activity of a modern manager were identified; recording surveys of teachers and students were conducted.

2. Experimental work (2011-2018) was conducted among teachers and undergraduate students, during which the proposed methodology was tested.

3 . The results obtained at the final stage of the experiment (2020) were analyzed, conclusions were drawn and recommendations were made.

The purpose of the questionnaires was to determine the general picture of the work of managers, to identify management difficulties and the adequacy of the study material, to study the needs of students.

The purpose of the recording experiment was to ask: Do students know who the manager is and his or her managerial job?

The purpose of the instructional experiment was to test the effectiveness of the material developed by the researcher, the formation of research qualities in the manager.

The following were included in the experimental work tasks:

1) development of materials that form managerial qualities in managers in the study of the disciplines of the pedagogical cycle;

2) identification of conditions and advanced technologies for the acquisition of management skills in practical training; 
3) creation of a system of training tools for managers to establish management qualities;

4) monitoring the dynamics and evaluation of the proposed system of works, the organization of quality control;

5) conducting tests, trainings with teachers and students to approve teaching aids.

In the experimental work, training materials specially developed by the researcher were used.

Thus, the whole research process conducted during the work on the dissertation confirmed the correctness of the hypotheses we chose, the appropriateness of the tasks presented in the defense, and that they were performed in the course of the work. The pedagogical methods used helped to achieve the goals set in the work.

Based on the results of the study, the following scientific and methodological recommendations were developed:

1. It is necessary to develop and systematize effective ways of strategic planning in management.

2. When preparing for a large educational project, it is necessary to determine the extent to which the process of implementation of this project corresponds to the established plan, to develop technologies for its effective management.

\section{REFERENCES:}

1. AxliddinovR.Sh., Oldroyd D., Khodjaev A., Nasyrova F., Kamilova M. Upravlenieobrazovaniem v Uzbekistane: problemy, poisk, resheniya. - Tashkent: ES TASIS, 1999.

2. BelkerLorin B., Topchik Harry S. Nachinayushchiy manager: Prakticheskoerukovodstvo / Per. s angl. SPb: Izd-vo «Dilya», 2006. - 304 p.

3. Druker, Peter F. Management practice: Per. s angl.Uch.posob. - M .: Izdat.dom «Williams», 2008. - $400 \mathrm{p}$.

$4 . \quad$ Lazarev V.S. Upravlenieobrazovaniemnaporogenovoyep oxi // Pedagogika, 1995, № 5. - C. 12.
5. Meskon M., Albert M., Xedouri F. Fundamentals of management. - $\mathrm{M}$.: Delo, 2002.

6. QurbanovSh.E., Seytxalilov E.A. Education quality management. Tashkent: Turon-Iqbol, 2006. - 592 p. 